\title{
Role of angiotensin-converting enzyme as prognostic marker in thoracic trauma: A prospective observational study
}

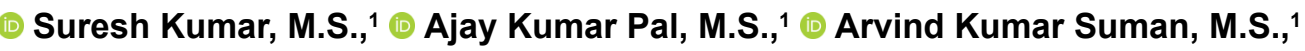

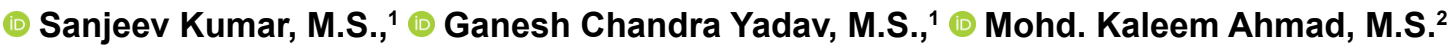

${ }^{1}$ Department of Surgery, King George's Medical University, Lucknow-India

${ }^{2}$ Department of Biochemistry, King George's Medical University, Lucknow-India

\begin{abstract}
BACKGROUND: Chest injuries, accounting for $25 \%$ of all trauma-related deaths, are one of the main causes of death in young adults. Our priority is the early identification of life-threatening injuries both immediate and delayed. The role of various biomarkers, such as Clara cell protein 16, von Willebrand factor, interleukin-6, tumor necrosis factor, and angiopoietin, has been studied in trauma-related acute respiratory distress syndrome (ARDS). Serum angiotensin-converting enzyme (ACE) levels have been studied in non-trauma-related ARDS. The aim of this prospective observational study was to evaluate the role of ACE levels as a prognostic marker in thoracic trauma.
\end{abstract}

METHODS: A prospective observational study was conducted to evaluate serum ACE levels in thoracic trauma patients and to explore its prognostic potential with regard to clinical outcome. A total of 48 thoracic trauma patients were included in the study.

RESULTS: The mean ACE level in the study population was $66.54 \pm 1$ I.I8. A strong positive correlation was found among serum ACE levels and Thoracic Trauma Severity Score (TTSS).

CONCLUSION: Our study demonstrates that serum ACE levels are increased in thoracic trauma patients with higher levels, indicating the severe nature of trauma in concordance with increased TTSS scores.

Keywords: Angiotensin-converting enzyme; chest; injury; marker; prognosis.

\section{INTRODUCTION}

Chest injuries, accounting for $25 \%$ of all trauma-related deaths, are one of the main causes of death in young adults. ${ }^{\left[{ }^{[}\right]}$ These injuries can be managed by pain management, oxygenation, tube thoracostomy, or surgery. Mortality can occur immediately after thoracic injury or in the delayed phase due to respiratory failure. ${ }^{\left[{ }^{[}\right]}$The early identification of patients with trauma-related acute respiratory distress syndrome (ARDS) with grave prognosis is of utmost importance, and various biomarkers in blood and bronchoalveolar lavage fluid have been studied till date in this regard, e.g., Clara cell protein I6, von Willebrand factor, interleukin-6, tumor necrosis factor, angiopoietin-2, histones, selectins, and mitochondrial DNA. [2-7] In this respect, angiotensin-converting enzyme (ACE), which plays a central role in generating angiotensin II from angiotensin I in the renin-angiotensin system (RAS), assumes importance because the capillary blood vessels in the lung are one of the major sites of ACE expression and angiotensin II production in the human body. ${ }^{[8]}$ Though the role of RAS has been implicated in the pathogenesis of pulmonary hypertension and pulmonary fibrosis in chronic lung diseases, ${ }^{\left[{ }^{[9]}\right.}$ recent studies indicate that the RAS also plays a critical role in acute lung injury and ARDS. ${ }^{[9]}$ Thoracic trauma also increases the chances of acute lung injury and ARDS with or without fatality. Thus, the RAS appears to play a critical role in the pathogenesis of trauma-related acute lung injury. Therein lie the possibility of therapeutic altering of ACE activity to affect the prognostic outcome in severe thoracic trauma. Therefore, we planned a prospective observational study to

Cite this article as: Kumar S, Pal AK, Suman AK, Kumar S, Yadav GC, Ahmad MK. Role of angiotensin-converting enzyme as prognostic marker in thoracic trauma: A prospective observational study. Ulus Travma Acil Cerrahi Derg 2019;25:350-354.

Address for correspondence: Sanjeev Kumar, M.D.

Department of Surgery, King George's Medical University 22600 Lucknow - India

Tel: 05222258I80 E-mail: drsanjeevkgmc@gmail.com

Ulus Travma Acil Cerrahi Derg 2019;25(4):350-354 DOI: 10.5505/tjtes.2018.14894 Submitted: 10.07.2018 Accepted: 23.10.2018 Online: 07.08.2019

Copyright 2019 Turkish Association of Trauma and Emergency Surgery 
evaluate the levels of $A C E$ in traumatic lung injury patients and to compare its level with Thoracic Trauma Severity Score (TTSS). We correlate the level of ACE with the outcome (discharge, ARDS, and mortality) of patients, so that its role can be established as a predictive marker for the severity and prognosis of traumatic parenchyma lung injury.

\section{MATERIALS AND METHODS}

After obtaining approval from the institutional ethical committee, this prospective observational study was conducted in the Department of Surgery, in collaboration with the Department of Biochemistry. All consecutive adult (aged $>18$ years) patients of isolated lung injury (blunt or penetrating) coming to the trauma center and surgery emergency of King George Medical University Lucknow, UP, India from July 2015 to August 2016 were included in the study. Informed consent was obtained from the patients. Patients with polytrauma, pre-existing pulmonary or renal disease, and any other significant co-morbid medical or surgical illness were excluded from the study. The demographic data of all patients, mode of injury, any intervention, serum ACE levels at the time admission, and outcomes (discharge, ARDS, and mortality) were evaluated.

\section{Data Collection}

After performing a thorough clinical examination, noting down associated injuries along with exclusion of patients with obvious polytrauma, chest radiograph examination and ultrasonography (focused assessment with sonography in trauma) abdomen with exclusion of patients with abdominal trauma were performed. Patient's clinical condition guided by laboratory parameters and radiological investigations was the main determinant of further management as per standard practice guidelines for thoracic trauma followed upon in the institution, and it was not affected by the observational nature of the study.

\section{Procedure}

Venous blood sample $(5 \mathrm{~mL})$ was withdrawn from patients with traumatic lung injury on the day of admission and stored in a deep freezer at $-80^{\circ} \mathrm{C}$. It was transported in an icebox to the Department of Biochemistry for storage at $-80^{\circ} \mathrm{C}$. It was centrifuged at $3000 \mathrm{~g}$ for $10 \mathrm{~min}$ for separation of serum. The estimation of serum ACE by enzyme linked immunosorbent assay (ELISA) kit was performed according to the manufacturer's protocol.

\section{Statistical Analysis}

Student's t-test was used to test the significance of the mean of two groups, and paired t-test was used to test the significance of change in variable. Chi-square test was used to test the significance of contingency tables. Values are expressed as mean and standard deviation. A $p$ value $<0.05$ was accepted as significant.

\section{RESULTS}

\section{Demographic Profile of the Patients}

The duration of the study was I year. A total of 48 patients with isolated traumatic lung injury (by both penetrating and blunt trauma) were enrolled into the study. The mean age of the patients was $41.48 \pm 4.37$ (range 13-70) years. The majority of the patients were male, with a study population of 44 ( $91.67 \%)$. A bimodal distribution of age was seen at maximum $(n=10, \%=2 I)$ between $2 I$ and 30 years and $5 I$ and 60 years, followed by those aged between $4 I$ and 50 years $(n=9, \%=19)$.

\section{Injury Pattern}

Road traffic accident ( $n=26, \%=54)$ followed by fall from height $(n=12, \%=25)$ were common modes of injury, whereas penetrating trauma by sharp objects (low velocity), firearm chest injury (high velocity), and bull horn injury were other modes of injury (Table I). In most of the patients, lung contusion alone was the most consistent finding (50\%), followed by contusion and collection of both (31\%). The rest of them had collection alone $(6 \%)$, subcutaneous emphysema (16\%), pneumothorax $(2 \%)$, and subcutaneous hematoma ( $2 \%$ ) (Table I).

\section{Serum ACE Levels}

The serum level of $A C E$ in different patients was evaluated by using an ELISA kit, and the value varied between 30 and 90 $\mu \mathrm{g} / \mathrm{L}$. The mean ACE levels in our patient was $66.54 \pm \mathrm{II}$. 18 . Six range groups were made viz. $\leq 40,4 I-50,5 I-60,6 I-70$, $7 \mathrm{I}-80$, and $>80$. Most of the patients had levels $6 \mathrm{I}-70$ (4I\%), followed by $7 \mathrm{I}-80$ (3I\%) (Table I).

\section{Thoracic Trauma Severity Score}

TTSS, which consists of five grades based on $\mathrm{PaO}_{2} / \mathrm{FiO}_{2}$ ratio, rib fracture, contusion of the lung, pleural involvement, and age of the patient, was calculated in each patient. The mean TTSS score was $8.52 \pm 4.42$ (Table I).

\section{Correlation of Serum ACE with the Length of Hospital Stay, Complications, and Outcome}

Patients with the highest duration of hospital stay (mean 16.4 \pm 3.26 days) had higher ACE levels in the range of 7 I -80 $\mu \mathrm{g} / \mathrm{L}$, and those with the least duration of stay ( 2 days) had ACE levels $<40 \mu \mathrm{g} / \mathrm{L}$ (Table 2, Fig. I). Patients with ACE levels $>80 \mu \mathrm{g} / \mathrm{L}$ had lesser hospital stay with higher incidence of expiry among them. Patients without complications had a mean level of ACE of 63.I, whereas those with complications of pneumonitis, empyema thoracis, ARDS, and sepsis had mean levels of ACE ( $\mu \mathrm{g} / \mathrm{L})$ of $66.4,75.3,76.1$, and 87.5 , respectively (Fig. 2).

\section{Correlation of TTSS with the Length of Hospital Stay, Complications, and Outcome}

Patients with the highest duration of hospital stay (mean 13.4 days) had higher TTSS in the range of II-15, but TTSS was 
Table I. Patient characteristics, demographics, injury pattern, complications, ACE levels, TTSS scores, and final outcome

\begin{tabular}{|c|c|c|c|}
\hline & $\mathbf{n}$ & $\%$ & Mean \pm SD \\
\hline Age (years) & & & $41.48 \pm 4.37$ \\
\hline Sex, males & 44 & 91.6 & \\
\hline Length of hospital stay, days & & & $8.95 \pm 3.54$ \\
\hline \multicolumn{4}{|l|}{ Mode of injury } \\
\hline Road traffic accident & 26 & 54 & \\
\hline Fall from height & 12 & 25 & \\
\hline Penetrating trauma (low velocity) & 3 & 6.25 & \\
\hline Penetrating trauma (high velocity) & 3 & 6.25 & \\
\hline Others & 4 & 8.33 & \\
\hline \multicolumn{4}{|l|}{ Type of thoracic injury } \\
\hline Pleural collection (only) & 3 & & \\
\hline Pulmonary contusion (only) & 24 & & \\
\hline Pleural collection and pulmonary contusion & 15 & & \\
\hline \multicolumn{4}{|l|}{ Pneumothorax (only) } \\
\hline Subcutaneous hematoma (only) & 3 & & \\
\hline Rib fractures with other associated pleuro-parenchymal injuries & 39 & & \\
\hline No chest wall or pleuro-parenchymal injury & 3 & & \\
\hline \multicolumn{4}{|l|}{ Complications } \\
\hline No complication & 34 & & \\
\hline Pneumonitis & 2 & & \\
\hline Empyema thoracis & 2 & & \\
\hline Adult respiratory distress syndrome & 9 & & \\
\hline Sepsis & I & & \\
\hline Serum ACE levels, $\mu g / M L$ & & & $66.54 \pm 11.18$ \\
\hline \multicolumn{4}{|l|}{ Range of ACE levels, duration of stay (days) } \\
\hline$\leq 40$ & I & 2.08 & $2.0 \pm 0$ \\
\hline $4 I-50$ & 2 & 4.16 & $3.5 \pm 1.0$ \\
\hline $5 I-60$ & 7 & 14.58 & $5.85 \pm 0.90$ \\
\hline $6 I-70$ & 20 & 41.66 & $7.55 \pm 1.23$ \\
\hline $7 I-80$ & 15 & 31.25 & $16.4 \pm 3.26$ \\
\hline$>80$ & 3 & 6.25 & $9.0 \pm 1.0$ \\
\hline TTSS scores & & & $8.52 \pm 4.42$ \\
\hline \multicolumn{4}{|l|}{ Range of TTSS } \\
\hline $0-5$ & 10 & 20.83 & $5.0 \pm 1.63$ \\
\hline $6-10$ & 22 & 45.83 & $8.05 \pm 1.99$ \\
\hline $11-15$ & 13 & 27.08 & $13.4 \pm 3.53$ \\
\hline $16-20$ & 3 & 6.25 & $9.0 \pm 1.0$ \\
\hline \multicolumn{4}{|l|}{ Final outcome } \\
\hline Discharge & 42 & 87.5 & \\
\hline Ventilation & 3 & 6.25 & \\
\hline Expiry & 3 & 6.25 & \\
\hline
\end{tabular}

ACE: Angiotensin-converting enzyme; TTSS: Thoracic Trauma Severity Score; SD: Standard deviation.

highest (16-20) in patients with a duration of stay of $9.0 \pm 1$ days due to the higher incidence of expiry (Fig. I). Patients without complications had a mean value of TTSS of 7.2, whereas those with complications of pneumonitis, empyema 


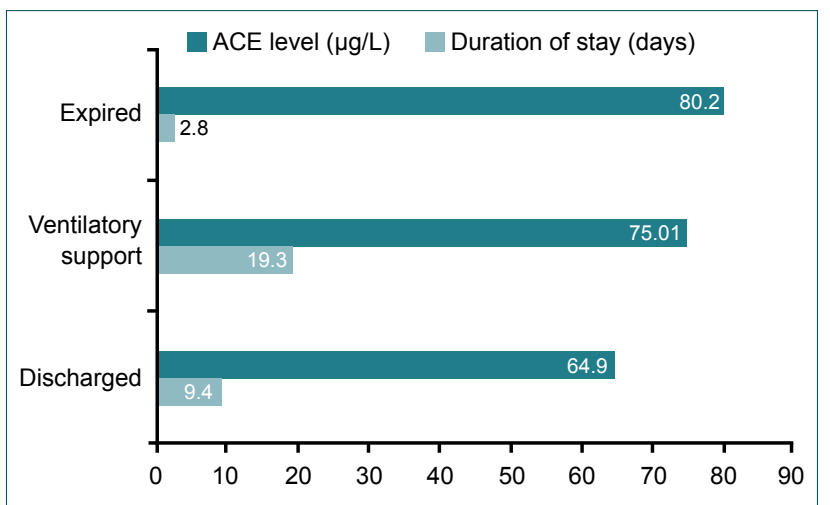

Figure 1. Serum ACE levels, patient outcome, and length of stay.

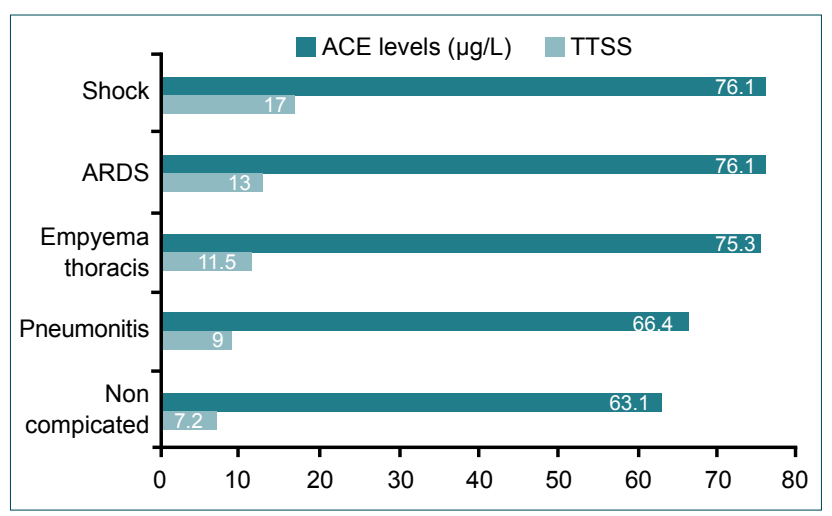

Figure 2. Serum ACE levels and complications.

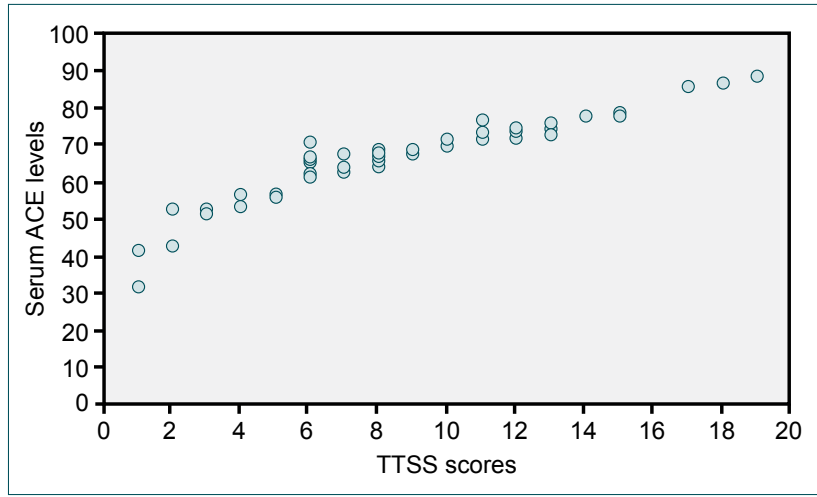

Figure 3. Correlation of TTSS and serum ACE levels.

thoracis, ARDS, and sepsis had mean levels of TTSS of 9, II.5, 13, and 17 respectively (Fig. I). When TTSS value was calculated for each patient, most of the patients had a range of TTSS of 6-10 (45\%), followed by ranges of II-I5 (27\%) and $0-5$ (20\%) (Fig. 2).

\section{Correlation of TTSS with Serum ACE Levels}

On correlating TTSS and serum ACE in our patients, a strong positive correlation was found (coefficient of determination=0.86) (Fig. 3).

\section{DISCUSSION}

Our prospective observational study on 48 patients with iso- lated thoracic trauma severity and ACE levels indicates that serum ACE level is increased in patients with severe thoracic trauma, complications (pneumonitis, empyema thoracis, ARDS, and sepsis), and mortality. It was also suggested that serum ACE level with a high correlation with TTSS may play a potential biomarker role for injury severity in thoracic trauma. Though there are several studies conducted on biomarkers of lung injury in ARDS, most of these were performed on nontraumatic causes of ARDS ${ }^{[10-13]}$ with in critical care settings and based on retrospective collection of data. Prospective studies on a novel biomarker, such as serum ACE, for prognostication of thoracic trauma patients are still lacking. Thus, the search of a biomarker for lung injury in thoracic trauma is still ongoing.

Serum ACE level may be potentially altered in thoracic trauma as pulmonary capillaries being the site of expression of $A C E$ may be damaged in thoracic trauma. In a previous study by Orfanos et al..[14] pulmonary capillary endothelium band ACE was altered in 22 critically ill patients with a decrease in early stage acute lung injury. However, their study was conducted in an intensive care unit setting and critically ill patient only. In our prospective study, we have performed an evaluation of serum ACE levels, which were hypothesized to be increased as a result of pulmonary endothelial damage in severe thoracic trauma.

Various scoring systems, such as TTSS and Lung Organ Failure Score, have been used to predict the risk fraction of ARDS in trauma settings. In our study, we have also found an increased TTSS score in patients with complications of thoracic trauma, and a significant positive correlation was found between serum ACE levels and TTSS scores. This suggests the role of serum ACE levels as a potential prognostic marker.

The main limitation of our study is its small sample size and the non-inclusion of any radiological investigation (e.g., multiple detector computed tomography) for the evaluation of the extent of pulmonary change. One more point worth mentioning is that ACE level may be increased in inflammatory disorders, such as sarcoidosis and other medical conditions, such as diabetes, cirrhosis, hyperthyroidism, psoriasis, amyloidosis, human immunodeficiency virus, histoplasmosis, leprosy, lymphoma, and tuberculosis. Though we have excluded patients with medical disorders from our study, there is still a chance of false positive results. Future prospective studies with larger sample size with possible multi-institutional involvement and utilization of multiple regression analysis based on the prediction of risk outcome after consideration of clinical, radiological, and biochemical marker of thoracic injury along with various injury scoring systems are required for validation of our results. Nevertheless, to the best of our knowledge, this is probably the first study to evaluate the role of $\mathrm{ACE}$ as a prognostic marker in thoracic trauma patients.

\section{Conclusion}

Our study demonstrates that serum ACE levels are increased in thoracic trauma patients with higher levels, thereby indicat- 
ing the severe nature of trauma in concordance with increased TTSS scores. Thus, there exists a potential role of serum ACE levels as a prognostic marker in thoracic trauma. However, future studies are needed to support this conclusion.

\section{Conflict of interest: None declared.}

\section{REFERENCES}

1. Nirula R, Pintar FA. Identification of vehicle components associated with severe thoracic injury in motor vehicle crashes: a CIREN and NASS analysis. Accid Anal Prev 2008;40:137-41. [CrossRef]

2. Kumar S, Pandey A, Kumar S, Singh SP, Ahmad A, Ahmad MK. Diagnostic and prognostic efficacy of Von Willebrand factor and Clara cell in traumatic lung injury. Indian J Thorac Cardiovasc Surg 2018;34: 125-8.

3. Agrawal A, Matthay MA, Kangelaris KN, Stein J, Chu JC, Imp BM, et al. Plasma angiopoietin-2 predicts the onset of acute lung injury in critically ill patients. Am J Respir Crit Care Med 2013;187:736-42. [CrossRef]

4. Calfee CS, Gallagher D, Abbott J, Thompson BT, Matthay MA; NHLBI ARDS Network. Plasma angiopoietin-2 in clinical acute lung injury: prognostic and pathogenetic significance. Crit Care Med 2012;40:1731-7. [CrossRef]

5. Zhang Y, Guan L, Yu J, Zhao Z, Mao L, Li S, et al. Pulmonary endothelial activation caused by extracellular histones contributes to neutrophil activation in acute respiratory distress syndrome. Respir Res 2016;17:155.

6. Donnelly SC, Haslett C, Dransfield I, Robertson CE, Carter DC, Ross
JA, et al. Role of selectins in development of adult respiratory distress syndrome. Lancet 1994;344:215-9. [CrossRef]

7. Gan L, Zhong J, Zhang R, Sun T, Li Q, Chen X, et al. The Immediate Intramedullary Nailing Surgery Increased the Mitochondrial DNA Release That Aggravated Systemic Inflammatory Response and Lung Injury Induced by Elderly Hip Fracture. Mediators Inflamm 2015;2015:587378.

8. Biller H, Zissel G, Ruprecht B, Nauck M, Busse Grawitz A, Müller-Quernheim J. Genotype-corrected reference values for serum angiotensin-converting enzyme. Eur Respir J 2006;28:1085-90. [CrossRef]

9. Guang C, Phillips RD, Jiang B, Milani F. Three key proteases--angiotensinI-converting enzyme (ACE), ACE2 and renin-within and beyond the renin-angiotensin system. Arch Cardiovasc Dis 2012;105:373-85.

10. Khan A, Benthin C, Zeno B, Albertson TE, Boyd J, Christie JD, et al. A pilot clinical trial of recombinant human angiotensin-converting enzyme 2 in acute respiratory distress syndrome. Crit Care 2017;21:234.

11. Lesur O, Langevin S, Berthiaume Y, Légaré M, Skrobik Y, Bellemare JF, et al. Outcome value of Clara cell protein in serum of patients with acute respiratory distress syndrome. Intensive Care Med 2006;32:1167-74.

12. Yan $Y, R a o$ Q. Biomarkers in the diagnosis and prognostic assessment of acute respiratory distress syndrome. J Transl Intern Med 2014;2:160-3.

13. Determann RM, Millo JL, Waddy S, Lutter R, Garrard CS, Schultz MJ. Plasma CC16 levels are associated with development of ALI/ARDS in patients with ventilator-associated pneumonia: a retrospective observational study. BMC Pulm Med 2009;9:49. [CrossRef]

14. Orfanos SE, Langleben D, Khoury J, Schlesinger RD, Dragatakis L, Roussos C, et al. Pulmonary capillary endothelium-bound angiotensinconverting enzyme activity in humans. Circulation 1999;99:1593-9.

\section{ORİJINAL ÇALIŞMA - ÖZET}

\section{Toraks travmasında bir prognostik belirteç olarak anjiyotensin dönüştürücü enzimin rolü:} Bir ileriye yönelik gözlemsel çalışma

\section{Dr. Suresh Kumar, ${ }^{1}$ Dr. Ajay Kumar Pal, ${ }^{1}$ Dr. Arvind Kumar Suman, ${ }^{1}$ Dr. Sanjeev Kumar, \\ Dr. Ganesh Chandra Yadav, ${ }^{1}$ Dr. Mohd. Kaleem Ahmad ${ }^{2}$}

${ }^{1}$ Kral George's Tıp Üniversitesi, Cerrahi Anabilim Dalı, Lucknow-Hindistan

${ }^{2}$ Kral George's Tıp Üniversitesi, Biyokimya Anabilim Dalı, Lucknow-Hindistan

AMAÇ: Toraks yaralanmaları tüm travma nedenli ölümlerin \%25'inden sorumlu olup genç yetişkinlerde ölümün başlıca nedenlerinden biridir. Önceliğimiz hem travmanın hemen sonrası hem de geç dönemde yaşamı tehdit edici yaralanmaların erkenden tanımlanmasıdır. Clara hücre proteini 16 , von Willebrand faktörü, interlökin-6, tümör nekroz faktörü ve anjiyopoietin gibi değişik biyobelirteçlerin rolü travmayla ilişkili akut solunum sıkıntısı sendromunda (ASSS) incelendi. Serum anjiyotensin dönüştürücü enzim (ADE) düzeyleri travmayla ilişkili olmayan ASSS'de çalışıldı. Bu ileriye yönelik gözlemsel çalışmada, totraks travmasında bir prognostik belirteç olarak ADE düzeylerinin rolü değerlendirildi.

GEREÇ VE YÖNTEM: Toraks travma hastalarında serum ADE düzeylerini değerlendirme ve klinik sonuç açısından prognostik potansiyelini araştırma amacıyla bir ileriye yönelik gözlemsel çalışma yürütüldü. Çalışmaya toplam 48 toraks travma hastası dahil edildi.

BULGULAR: Çalışma popülasyonunda ortalama ADE değeri 66.54 I I . I8 U/L idi. Serum ADE düzeyleri ve Toraks Travması Şiddet Skoru (Thoracic Trauma Severity Score: TTSS) arasında güçlü bir korelasyon saptandı.

TARTIŞMA: Çalışmamız serum ADE düzeylerinin toraks travması hastalarında yükseldiğini, şiddetli travmanın yüksek TTSS'yle uyum içinde olduğunu göstermektedir.

Anahtar sözcükler: Anjiyotensin dönüştürücü enzim; belirteç; prognoz; toraks; yaralanma. 